\title{
The pendulum swings back: New authoritarian threats to liberal democratic constitutionalism
}

\section{Introduction}

At the close of the twentieth century, for political elites it was reasonable to believe that liberal democratic constitutionalism (LDC) was the ascendant political arrangement in states of the 'Global North' and, through colonialism, relatedly for states of the 'Global South'. LDC was presented as not only asserting a claim to superior normative validity undergirded by human rights, democracy and the rule of law - but also a claim to inevitability as a mode of governance. In the words of perhaps the most (in)famous articulation of this hopeful claim from its heady heyday, 'there is now no ideology with pretentions to universality that is in a position to challenge liberal democracy', which stands as 'the single universal standard'. ${ }^{1}$ While this sense of inevitably had its sceptics even at LDC's zenith, ${ }^{2}$ for a time its continued spread and ultimate triumph were not only a defensible prediction of the future, but plausibly the most convincing one.

Twenty-odd years later, LDC has not only failed to become a universal mode of political organization, but its traditional bastions have themselves suffered democratic backsliding. For the past decade, the most salient form of this has been internal crisis. ${ }^{3}$ As we observed following Trump, Brexit, and a general resurgence of far-right parties across the diverse polities, 'far right populist authoritarianism' poses an immediate threat to LDC. ${ }^{4}$ Yet, a year after Trump's defeat and with the EU having survived Brexit in part because states central to its integrity, such as France, have - so far - resisted far right populist leadership, the norms of constitutionalism have shown a measure of robustness. ${ }^{5}$ The possibility that LDC might

\footnotetext{
${ }^{1}$ F Fukuyama, The End of History and the Last Man (Free Press, New York, 1992) 45.

${ }^{2}$ Most famously, SP Huntington, 'Clash of Civilizations' (1993) 72(3) Foreign Affairs 22 was largely coterminous with Fukuyama's account.

${ }^{3}$ Of course, the influence of foreign meddling in these electoral events raises the question of how 'internal' they truly were, and whether technological and social changes are fundamentally upending traditional conceptions of popular national self-determination. See J Eisler, 'Constitutional Formalities, Power Realities, and Comparative Anglophone Responses to Foreign Campaign Meddling' (2021) 20 Election Law Journal 32. See also the recent brilliant analysis of the crisis of democracy emanating from Tory politics in the United Kingdom by A Ditter, 'Ignore His Lies: Boris Johnson is Leading an Assault on British Democracy. This Government is Hammering Away at the Foundations of a Free Society. Look to Warsaw to See Where That Can Lead', New Statesman, 13 December 2021.

${ }^{4} \mathrm{M}$ Kumm, J Havercroft, J Dunoff and A Wiener, "The End of "the West" and the Future of Global Constitutionalism' (2017) 6 Global Constitutionalism 1; J Havercroft, A Wiener, M Kumm and J Dunoff, 'Donald Trump as Global Constitutional Breaching Experiment' (2018) 7 Global Constitutionalism 1. The challenges to global constitutionalism have become a major theme in the scholarship; see, e.g., CM Koch, 'Varieties of Populism and the Challenges to Global Constitutionalism: Dangers, Promises and Implications' (2021) 10 Global Constitutionalism 400.

${ }^{5}$ This robustness inspired our last editorial: see J Shaw, J Eisler, J Havercroft, A Wiener and V Napoleon, 'After Trump' (2021) 10 Global Constitutionalism 1.

(c) The Author(s), 2022. Published by Cambridge University Press.
} 
ultimately be extinguished by far-right populism remains, but so far it has survived a number of traumatic political events internal to its established champions.

Comparing the position of LDC a few decades earlier to its current status also reveals what is possibly an even more dramatic shift. LDC's ascendance meant it appeared ready to displace illiberal and autocratic regimes that could not lay claim to its normative force; the pressure was directed by liberal democracy against other forms of organization. Recent events have shown not only the durability of illiberal regimes, but their capacity to undermine, sabotage and diminish the position of LDC in regimes where it has been well established.

Even more strikingly, these attacks have often invoked, relied upon or attempted to exploit the foundational values of LDC. ${ }^{6}$ Illiberal regimes have sought to seize territory of (established or aspiring) liberal polities by asserting rights of self-rule; the tension posed by universal human rights during a migration crisis has been exploited and even weaponized by illiberal polities hoping to challenge the liberal order; new technologies have been exploited by illiberal regimes to meddle with democratic values of self-rule and popular self-determination.

These challenges to LDC, in the guise of its own values, raise two linked, broad puzzles for students of global constitutionalism as an interdisciplinary field in law and political science. ${ }^{7}$ First, what are the macro-scale social and political conditions that not only make constitutionalism normatively tenable within distinct regulatory levels of polities, but also make it appealing compared with other modes of political organization? Making this project more challenging for LDC is a feature of its participation in the 'grand game' of regime selection: while authoritarian or ethno-populist regimes may undermine or sabotage the self-determination of other polities without compromising their core commitments, LDC takes as a justifying principle that a polity forges its own political organization. While LDC may offer arguments as to why it is a preferable and just arrangement - precisely the project undertaken by John Rawls in Political Liberalism ${ }^{8}$ - it is, if it wishes to retain its integrity, denied some realpolitik machinations.

The second question, inspired by the Rawlsian functional use of the values of LDC against liberal regimes, concerns what circumstances or conditions underlie such norms' legitimate invocation. It may be that the malign origins of the invocation of these norms significantly diminishes their values; or that any paradox is resolved if LDC values are universally adopted, thus reflecting the tension back at the authoritarian regimes that invoke them. However, it may also be that, taken in isolation and separated from their authoritarian origins, the tensions elicited by the weaponization of norms are valid. This would suggest that the values of LDC may face insoluble dilemmas, and that these dilemmas may be more common or salient where LDC is jockeying with ascendant and inimical modes of political organization.

\footnotetext{
${ }^{6} \mathrm{~A}$ related phenomenon has been the adoption of the rhetoric and, in modified forms, the principles of liberal constitutionalism even in non-constitutional regimes. As Fukuyama (1992: 45) notes, the rhetoric of democracy is now used to legitimate even regimes that do not satisfy standard expectations of democratic process. Likewise, China has advanced distinct conceptions of rule of law that claims its foundationalism but does not conform to the non-arbitrariness typical in Western understandings. See S Seppänen, Ideological Conflict and the Rule of Law in Contemporary China (Cambridge University Press, Cambridge, 2016) 32, 68.

${ }^{7}$ For the emergence of global constitutionalism as a subfield, see the discussion in A Wiener, AF Lang Jr, J Tully, M Poiares Maduro and M Kumm, of 'Why a New Journal on Global Constitutionalism?' (2012) 1(1) Global Constitutionalism 1.

${ }^{8}$ J Rawls, Political Liberalism (Columbia University Press, New York, 2005).
} 


\section{The authoritarian weaponization of the values of global constitutionalism}

Weaponization of the values of LDC against constitutional democracies has taken three significant forms: exploiting crises of migration, which raise tensions for the commitment to human rights; claims that ethnic collective self-determination grants autocratic regimes the right to annex or co-opt all or part of democratic regimes; and manipulating constitutionalism's commitment to speech and discourse rights to surreptitiously meddle (through new technology) in popular self-determination. In each context, the non-liberal actors leverage the values of LDC to erode or destabilize liberal constitutionalist polities.

\section{The immigration crisis and the liberal constitutionalist dilemma}

Events of the past decade have placed liberal democracies in a normative dilemma. Political, economic and ecological crises (which can themselves plausibly be attributed to the very polities to which many refugees wish to migrate $)^{9}$ have resulted in migrants seeking refuge in developed liberal democracies. Given the commitment of LDC to recognizing the intrinsic value of persons and the subsequent universality of rights, managing refugee migration - crudely stated, excluding migrants from entry into polities - raises a fundamental tension: philosophically, national origin is arbitrary, and differentiating persons on its basis contravenes liberalism's Kantian inclinations. ${ }^{10}$ The presence of migration has been exploited domestically by far-right ethnonationalists within constitutionalist regimes. However, the use of immigration as an authoritarian tool of diplomacy, coercion and subversion is both more novel and, from a normative perspective, much starker.

The most pointed example of the weaponization of immigration against LDC has occurred along the Polish-Belorussian border, where migrants from the Middle East and Africa have sought entry to the European Union. Western officials have suggested that the authoritarian president of Belarus, Aleksandr Lukashenko, has deliberately admitted refugees from war-torn and economically deprived areas into Belarus and then funnelled them to the Polish border ${ }^{11}$ as a reprisal for Western condemnation of his allegedly fraudulent electoral victory in the 2020 and subsequent Western sanctions. ${ }^{12}$ The particular scenario is reminiscent of President Tayyip Erdogan's deployment of migration policy as a bargaining chip with the European Union when Western governments reacted

\footnotetext{
${ }^{9}$ Regarding the link between climate change and migration, see N Popovich and B Plumer, 'Who Has the Most Responsibility for Climate Change?', The New York Times, 12 November 2021, available at <https:// www.nytimes.com/interactive/2021/11/12/climate/cop26-emissions-compensation.html>; and J Podesta, 'The Climate Crisis, Migration, and Refugees' Brookings Institution, 25 July 2019, available at <https:// www.brookings.edu/research/the-climate-crisis-migration-and-refugees $>$. One can also look to the relationship between colonialism and refugee migration: see GK Bhambra, 'The Current Crisis of Europe: Refugees, Colonialism, and the Limits of Cosmopolitanism' (2017) 23 European Law Journal 395.

${ }^{10}$ See HO Yusuf and T Chowdhury, 'The Persistence of Colonial Constitutionalism in British Overseas Territories' (2019) 8 Global Constitutionalism 157.

${ }^{11}$ A Troianovski, M Pronczuk and A Magdziarz, 'West Accuses Belarus of Orchestrating Migrant Crisis at Polish Border', The New York Times, 9 November 2021, available at <https://www.nytimes.com/2021/11/09/ world/europe/poland-belarus-border-crisis.html>.

${ }^{12}$ Scott Neuman, 'Belarus President is Secretly Inaugurated Weeks After Disputed Election', NPR, 23 September 2021, available at <https://www.npr.org/2020/09/23/916000965/belarus-president-issecretly-inaugurated-weeks-after-disputed-election>.
} 
to his expansion of his executive powers in Turkey. ${ }^{13}$ However, the Belarus-Poland crisis presents additional layers: according to Western powers, Lukashenko is acting as a proxy for Russia in his efforts to undermine the European Union, a constitutional arrangement forged in cosmopolitan ethnopluralism rather than autocratic ethnonationalism; and the engagement with Poland in particular targets a state that faces concerns of far-right democratic backsliding based in ethnonationalism - precisely the type of drift rightward driven by anti-immigrant xenophobia. As such, the Belarus migration crisis is not merely a policy negotiation in which migrants have been instrumentalized, but a basic struggle over the question of whether LDC values and the cosmopolitan ethos can be reconciled with the pressures - normative and logistical - of refugee migration when it is deployed by opponents to those values.

These situations put constitutionalism under pressure at multiple levels. The use of refugees as a political weapon queries how the commitment to distinctly human rights that is a defining feature of LDC can be reconciled with the preferential treatment of one's own citizens. The use of refugees as a weapon by autocratic regimes to apply pressure on liberal democracies specifically exploits this tension to emphasize the limits of such cosmopolitan norms. ${ }^{14}$ Furthermore, the specific channels of normative appeal in the context of ethnopopulism ground the refugee crisis in democratic autonomy. The refugee crises are weaponized not only to elicit a particular crisis at the border, but to sway popular sentiment against cosmopolitan constitutionalism. As such, leveraging migration crisis not only strengthens the particular autocratic regimes exacerbating the refugee crises, but cynically increases the appeal of such autocratic, anti-cosmopolitan regime types, given that autocratic regimes are often less likely to be bound by such deontologically universalist commitments. The state to whom this autocratic appeal has most recently been made, Poland, is precisely a regime at risk of backsliding into such autocracy, and the immediate motivation for the established autocratic regimes is to retaliate against claims that the political procedures by which autocrats have entrenched themselves betray a legitimate democratic process.

\section{Popular self-determination and territorial annexation}

A second means by which autocracies have sought to undermine the standing of LDC is by asserting a normative right to annex or incorporate liberal democratic (or democratizing) polities. The appropriate terms of national self-determination elicit thorny questions of boundary-drawing and the appropriate role of identity in defining national contours. ${ }^{15}$ However, the autocratic challenge to constitutionalism is distinctive because it uses these norms of self-determination to aggrandize regimes that, ironically, fail to advance self-determination in practice.

The longest-bubbling conflict of this type involves China's asserted claim to authority over Taiwan. The People's Republic of China has asserted this as a matter of normative right, fundamentally framed in the ideal that the Chinese people comprise

\footnotetext{
${ }^{13}$ 'Erdogan Threatens to Scrap EU-Turkey Migrant Deal', BBC, 16 March 2017, available at <https:// www.bbc.co.uk/news/world-europe-39294776>.

${ }^{14}$ For an examination of the precarious form of "rightlessness" in which most asylum seekers find themselves under our current global regime of human rights, see A Gündogdu, Rightlessness in an Age of Rights: Hannah Arendt and the Contemporary Struggles of Migrants (Oxford University Press, Oxford, 2014).

${ }^{15}$ See FG Whelan, 'Prologue: Democratic Theory and the Boundary Problem' (1983) 25 Nomos 13, 31.
} 
a single polity, and that assertion by Taiwanese residents of independent sovereignty illegitimately disregards this unified status. ${ }^{16}$ Furthermore, the formal Chinese position has asserted that Taiwanese claims that reunification can only occur if mainland China democratizes are hollow on the ground that China itself can claim a version of legitimate democracy. Despite this, as has been thoroughly explored by leading scholars in Global Constitutionalism, it seems incontestable that contemporary Taiwan (the Republic of China) adheres to the fundamental norms of LDC - that is, human rights, democracy, and the rule of law - with a clarity that mainland China (the People's Republic of China) does not. ${ }^{17}$

The efforts by Crimea and Donetsk to secede from Ukraine - efforts supported by Russia through both covert and explicit military aid - comprise a more recent and vivid interference with a constitutionalizing democracy. These regions have asserted a right to independence. However, scholars and the international community have indicated that these assertions are illegal and violate Ukraine's territorial integrity and power of selfdetermination. ${ }^{18}$ Yet, with Russian military and logistical support, Donetsk and Crimea have assumed de facto independence; Russia has used these events to continually challenge and harass Ukraine. ${ }^{19}$ Beyond harassing its democratizing neighbour, Russian intervention in Ukraine is a means by which an autocratic power, led by a strongman dictator, can signal the fragility of democratic norms in the international community. ${ }^{20}$

\footnotetext{
${ }^{16}$ Taiwan Affairs Office and the Information Office of the State Council, 'The One-China Principle and the Taiwan Issue'(2004), available at <http://en.people.cn/features/taiwanpaper/taiwan.html>. Cf. H Stockton, 'National Identity on Taiwan: Causes and Consequences for Political Reunification' (2002) 9 American Journal of Chinese Studies 155, 156 (concluding that the 2000 election in Taiwan was a moment of "democratic consolidation" that diminishes the likelihood of reunification with China).

${ }^{17}$ Constitutionalism in mainland China has been extensively analysed within the pages of Global Constitutionalism itself. China's own treatment of constitutionalism presents a number of nuances, but defies standard prerequisites for satisfying constitutionalist norms. There is a 'significant lack of judicial autonomy in China': see S Bian, 'Political but Incontestable: A Review of "Political Constitutionalism" in China' (2021) 10 Global Constitutionalism 10, 14, contravening a basic requirement of the rule of law; this characteristic is contextualized by the dictatorial nature of Chinese governance, which, while it may rely on legal formalism as a structuring mechanism, can 'suspend formal rules when political expediency so requires': see S Seppanen, 'Formalism and Anti-formalism in the Chinese Communist Party's Governance Project' (2021) 10 Global Constitutionalism 290, 292. DKC Huang and NNT Li, 'Why China Finds It Difficult to Appreciate Democracy' (2019) 8 Global Constitutionalism 332, 337 argue that 'China finds democracy difficult to appreciate from a historical perspective' thanks to its longitudinal conceptualization of political authority. Conversely, Taiwan has buttressed its commitment to liberal constitutionalist values such as democracy and human rights: see CC Lin, 'Global Constitutionalism in Taiwan' (2021) 10 Global Constitutionalism 275.

${ }^{18}$ S Cavandoli, 'The Unresolved dilemma of self-determination: Crimea, Donetsk and Luhansk' (2016) 20 International Journal of Human Rights 875, 884 (observing secession is only valid for a subregion that has traditionally been oppressed or colonized); Y Shany, 'Does International Law Grant the People of Crimea and Donetsk a Right to Secede? Revisiting Self-Determination in Light of the 2014 Events in Ukraine' (2014) 21 Brown Journal of World Affairs 233 (observing the secession undermines national self-determination and has been condemned by the international community).

${ }^{19} \mathrm{P}$ Kirby, 'Is Russia Preparing to Invade Ukraine? And Other Questions', BBC, 10 December 2021, available at <https://www.bbc.co.uk/news/world-europe-56720589>.

${ }^{20} \mathrm{E}$ Reumer and AS Weiss, 'Ukraine: Putin's Unfinished Business', Carnegie Endowment for International Peace, 12 November 2021, available at <https://carnegieendowment.org/2021/11/12/ukraine-putin-s-unfin ished-business-pub-85771>.
} 
Thus, the two great autocratic powers of the world are not only seeking to expand their political authority by displacing democracies, but legitimizing their conduct through the invocation of LDC norms. The use of referendums in the sub-regions of Ukraine and the invocation of national unity by the PRC both vindicate functional undermining of the reach of LDC values by the principle of global self-determination.

\section{Electoral discourse, free speech and technology-enabled foreign meddling}

Not all the assaults on LDC by authoritarian regimes have taken the form of pressure against borders. The most insidious and perhaps notorious autocratic assaults against LDC self-rule have been covert disinformation campaigns accomplished largely through social media and directed against voters - although, ironically enough, and complicating any claim to the normative high ground, the West also has a long history of interfering in other nations' domestic politics, often with unsettling colonial overtones. ${ }^{21}$ This direct interference with popular democratic decision-making seeks to alter electoral outcomes as well as polarize and distort 'natural' formation of political preferences and identities. The most famous of these campaigns were directed against America by Russia during the 2016 and 2020 presidential elections, but the phenomenon is recognized as a threat to democracy more broadly. ${ }^{22}$ The campaigns relied in particular on state sponsorship of false or biased information that was introduced to users through algorithm-driven social media feeds, often on Facebook and Twitter. ${ }^{23}$

The aspect of such interference that has received the most attention is its exploitation of new technologies and forms of communication to appeal directly to voters. Yet the weight of such appeals is premised, both political and philosophically, upon voters' own preferences legitimately determining political outcomes. The point of entry for such meddling is not only the minimal procedural commitment to democracy that requires elections to select representatives, but broader liberal norms of free speech, information

\footnotetext{
${ }^{21}$ See, for example, J. Godinez, 'The Vested Interest Theory: Novel Methodology Examining US-Foreign Electoral Intervention' (2018) 11 Journal of Strategic Security 1.

${ }^{22} \mathrm{~S}$ McKay and C Tenove, 'Disinformation as a Threat to Deliberative Democracy' (2021) 74 Political Research Quarterly 703; E Brattberg and T Maurer, 'Russian Election Interference: Europe's Counter to Fake News and Cyber Attacks' Carnegie Endowment for International Peace, 23 May 2018, available at https:// carnegieendowment.org/2018/05/23/russian-election-interference-europe-s-counter-to-fake-news-andcyber-attacks-pub-76435; LA Ringhand, 'Foreign Election Interference: Comparative Approaches to a Global Challenge' (2021) 20 Election Law Journal 2; N Witzleb and M Paterson 'Micro-targeting in Political Campaigns: Political Promise and Democratic Risk', in U Kohl and J Eisler (eds), Data-Driven Personalisation in Markets, Politics and Law (Cambridge University Press, Cambridge, 2021), 223-240. While Russia has received the predominant attention, other regimes have also been indicted for meddling, including North Korea and Iran. See, for example, 'Russia and Iran Tried to Influence 2020 Presidential Election, But China Did Not, Intelligence Report Says', The New York Times, 16 March and 17 April 2021, available at <https:// www.nytimes.com/live/2021/03/16/us/biden-news-today>; E Shim, 'Japan Warns of North Korea Election Meddling in United States', United Press International, 27 December 2019, available at <https://www.upi. com/Top_News/World-News/2019/12/27/Japan-warns-of-North-Korea-election-meddling-in-UnitedStates/9491577398112>.

${ }^{23}$ US State Department, GEC Special Report: August 2020 Pillars of Russia's Disinformation and Propaganda Ecosystem (2020), available at <https://www.state.gov/wp-content/uploads/2020/08/Pillars-of-Russia \%E2\%80\%99s-Disinformation-and-Propaganda-Ecosystem_08-04-20.pdf >; see also J Eisler, 'Constitutional Formalities, Power Realities, and Comparative Anglophone Responses to Foreign Campaign Meddling' (2021) 20 Election Law Journal 32. (describing parallels between efforts to meddle in US and UK elections).
} 
exchange and genuine choice - in short, a democratic process sustained by human rights and rule of law, including in the context of new technologies. ${ }^{24}$ In seeking to shift the outcomes of democratic process, autocratic states have exploited liberal treatment of these new technologies by exploiting the subsequent vulnerabilities: unfamiliar cognitive blind spots in citizens, opportunities for fragmenting polities and technological alienation.

Such meddling exploits a bedrock norm of LDC - self-determination by citizens - to seek to sabotage LDC self-rule. It exploits the centrality of citizen will in the context of norms of human rights (particularly free expression and privacy) and rule of law (the neutral, non-paternalistic approach to internet governance adopted by most constitutionalist regimes). These are the attributes that are precisely absent from the regimes that undertake such meddling; their leaders assert political power over both norms of governance and citizen expression, and over the polity as a whole on an autocratic basis.

\section{Looking forward: Contextualizing and redeeming the fundamental norms of global constitutionalism}

The authoritarian exploitation of norms of global constitutionalism is, in the first instance, alarming: it suggests that the confidence and moral authority of constitutionalism is undermined not only by crises within constitutional polities, but by hijacking and erosion from alternative regime types. Yet these episodes also suggest a path forward, and ways of renewing LDC. That even autocratic regimes will appeal to these norms suggests their claim to universal validity. But it also suggests two questions that should be of interest to scholars and champions of liberal democratic self-rule.

First, what underlying conditions are necessary to sustain LDC in a normatively tenable form for both the Global North and the Global South in equal measure? The external challenges to LDC occur against a background of internal or system strain. Both the migration crises and the sought annexations reflect the challenges of differentiating between in-groups and out-groups that have more typically been identified through the lens of far-right ethnonationalism. That autocracies can leverage liberal norms to test the boundaries - normative and geographic - of LDC regimes shows that the problem is a universal one. This suggests that there may be a need to revise how global constitutional governance intersects with personal identity (a theme that echoes in the challenges of decolonization). ${ }^{25}$ The ability to exploit popular self-rule through new technology raises parallel questions of what preconditions of human rationality and civic society are necessary to sustain LDC principles.

Second, this autocratic weaponization of LDC values raises the more granular question of when invocation of such values is in good faith. Refugees can lay claim to human rights, and an ethnic minority in a polity can assert a right to appropriate recognition. But when these claims become tools of great powers hostile to these very values, parsing the nature and political implications of the invocation becomes a far more delicate process. The

\footnotetext{
${ }^{24}$ See M Aronczyk and S Budnitsky, 'Nation Branding and Internet Governance: Framing Debates Over Freedom and Sovereignty' in U Kohl (ed.), The Net and the Nation State (Cambridge University Press, Cambridge, 2017) 48-65 (observing that while constitutional democracies have adopted a liberal approach to internet governance, Russia has adopted a more paternalistic treatment of free speech); see also D Flonk, M Jachtenfuchs and AS Obendiek, 'Authority Conflicts in Internet Governance: Liberals vs. Sovereigntists?' (2020) 9 Global Constitutionalism 364.

${ }^{25}$ Jonathan Havercroft, Jacob Eisler, Jo Shaw, Antje Wiener and Val Napoleon, 'Decolonising Global Constitutionalism' (2020) 9 Global Constitutionalism 1, 1-6.
} 
invocations of LDC values that have genuine normative force must be differentiated from an unjust and instrumental invocations. Likewise, while the bedrock right to full selfdetermination by an electorate is inviolable, novel vulnerabilities- such as those elicited by the intersection of technology and political fragmentation - may require a subtle response. It may be that the meaning of 'full self-determination' itself requires further critical analysis in order to discipline the very circumstances that create vulnerability to autocratic meddling.

$$
\begin{array}{r}
\text { Jacob Eisler } \\
\text { University of Southampton, University Road, } \\
\text { Southampton SO17 1BJ, United Kingdom, } \\
\text { Email: J.Eisler@soton.ac.uk }
\end{array}
$$

Jonathan Havercroft University of Southampton, University Road, Southampton SO17 1BJ, United Kingdom, Email: j.havercroft@soton.ac.uk

Jo Shaw University of Edinburgh, Old College, South Bridge, Edinburgh EH8 9YL, United Kingdom, Email: jo.shaw@ed.ac.uk

Antje Wiener

Chair of Political Science especially Global Governance, Universität Hamburg, Faculty of Business and Social Sciences, Max-Brauer-Allee 60, 22767 Hamburg \& Hughes Hall, Cambridge University Email: antje.wiener@uni-hamburg.de

Susan Kang John Jay College of Criminal Justice, City University of New York, 524 West 59th Street, New York, NY, 10019

United States of America, Email:skang@jjay.cuny.edu

Cite this article: Eisler J, Havercroft J, Shaw J, Wiener A, Kang S. 2022. The pendulum swings back: New authoritarian threats to liberal democratic constitutionalism. Global Constitutionalism 11: 1-8, doi:10.1017/ S2045381722000028 